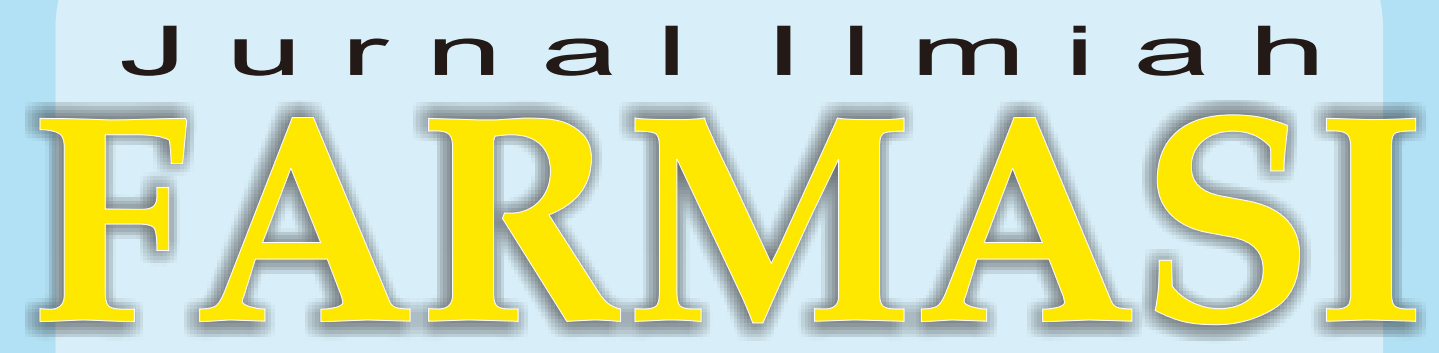

(Scientific Journal of Pharmacy) 
JURNAL ILMIAH FARMASI

(SCIENTIFIC JOURNAL OF PHARMACY)

PIMPINAN UMUM/ PENANGGUNG JAWAB

Dekan Fakultas Matematika dan Ilmu Pengetahuan Alam

Universitas Islam Indonesia

WAKIL PIMPINAN UMUM/ WAKIL PENANGGUNG JAWAB

Ketua Jurusan Farmasi FMIPA UII

\section{MITRA BESTARI}

1. Prof. Dr. Wiryatun Lestariana, Apt

2. Prof. Dr. Zullies Ikawati, Apt

3. Prof. Dr. Sudibyo Martono, Apt

4. Dr. Tedjo Yuwono, Apt

5. Prof. Dr. Dachriyanus, Apt

6. Prof. dr. Iwan Dwiprahasto, MMedSc, PhD

7. Prof. Dr. Lukman Hakim M.Sc., Apt

8. Prof. Dr. Achmad Fudholi, DEA, Apt

9. Prof. Dr. Ibnu Gholib Gandjar, DEA., Apt

\begin{tabular}{ll} 
& \multicolumn{1}{c}{ DEWAN EDITOR } \\
Ketua & : Saepudin, M.Si., Apt \\
Sekretaris & : Rochmy Istikharah, M.Sc., Apt. \\
Anggota & : Vitarani Dwi Ananda Ningrum, M.Si., Apt \\
& Okti R. Mafruhah, MSc., Apt \\
& Dimas Adhi Pradana, MSc., Apt. \\
& Fithria DA. Suryanegara, MSc., Apt. \\
& Ari Wibowo, S.Farm., Apt \\
& Arba Pramudita Ramadani, MSc., Apt. \\
& Oktavia Indrati, S.Farm., Apt.
\end{tabular}

Penerbit

Jurusan Farmasi Fakultas Matematika dan IImu Pengetahuan Alam Universitas Islam Indonesia

Alamat Penerbit Jurusan Farmasi FMIPA UII

Jl. Kaliurang Km. 14,4 Yogyakarta 55584

Telp. (0274) 896439 ext. 3047

Email: jif@uii.ac.id 


\title{
ISOLATION AND IDENTIFICATION OF FLAVONOIDS FROM WATER FRACTION OF SECANG WOOD (Caesalpinia sappan. L) WITH THIN LAYER CHROMATOGRAPHY AND UV-VIS SPECTROPHOTOMETRY METHODS
}

\author{
Lolyta Fournia Sari, Suparmi, Asih Triastuti
}

Program Studi Farmasi Universitas Islam Indonesia

\begin{abstract}
Aim of this research was to determine chemical structure of flavonoid from water fraction of Sappan wood. The flavonoid was isolated by Soxhlet xtraction using methanol and infundation. First, the detection of flavonoid was done using Thin Layer Chromatography (TLC) with statioram phase silica gel GF 254 and mobile phase ethyl acetate : acetyc acid $15 \%(9: 1 \mathrm{v} / \mathrm{v})$ smoked by $\mathrm{NH}_{3}$, and detected under UV $366 \mathrm{~nm}$, showed 5 spots with $\mathrm{hRf} 7,50,61,68$, and 80. Preparatif TLC was done to water fraction, disolveed in methanol and detected with UV-Vis spectrophotometry using diagnostic reagents $\mathrm{NaOH}, \mathrm{NaOAc}, \mathrm{NaOAc}+\mathrm{H} 3 \mathrm{BO}_{3}, \mathrm{AlCl}_{3}, \mathrm{ACl}_{3}+\mathrm{HCl}$ and compared with references. In fraction 1, 2, and 5 showed isoflavon with $7-\mathrm{OH}$, substitution oxygen in position six. In fraction 3 showed isoflavon with $7-\mathrm{OH}$, substitution oxygen in position six, 6,7 $\mathrm{diOH}$ in $\mathrm{A}$ ring, and $\mathrm{o}$-diOH in 6,7 or 7,8 . In fraction 4 showed isoflavon with $7-\mathrm{OH}$, substitution oxygen in $6, \mathrm{o}$-diOH in 6,7 or 7,8 and $5-\mathrm{OH}$.
\end{abstract}

Key Words: Caesalpinia Sappan. L, Flavonoid, TLC, UV-Vis Spectrophotometry 